\title{
Monocytes and Tissue Factor Promote Thrombosis in a Murine Model of Oxygen Deprivation
}

\author{
Charles A. Lawson, ${ }^{\star}$ Shi Du Yan,, Shi Fang Yan, ${ }^{\S}$ Hui Liao, ${ }^{\S}$ Yu Shan Zhou, ${ }^{\S}$ Joan Sobel, ${ }^{ף}$ Walter Kisiel, ${ }^{\star \star}$ David M. Stern, ${ }^{\S}$ \\ and David J. Pinsky" \\ *Department of Anesthesiology, ${ }^{*}$ Department of Pathology, ${ }^{\S}$ Department of Physiology, "Department of Surgery, and ${ }^{\mathbb{I}}$ Department of \\ Medicine, Columbia University, College of Physicians and Surgeons, New York 10032; and **Department of Pathology, The University of \\ New Mexico School of Medicine, Albuquerque, New Mexico 87131
}

\begin{abstract}
Clinical conditions associated with local or systemic hypoxemia can lead to prothrombotic diatheses. This study was undertaken to establish a model of whole-animal hypoxia wherein oxygen deprivation by itself would be sufficient to trigger tissue thrombosis. Furthermore, this model was used to test the hypothesis that hypoxia-induced mononuclear phagocyte (MP) recruitment and tissue factor (TF) expression may trigger the local deposition of fibrin which occurs in response to oxygen deprivation. Using an environmental chamber in which inhaled oxygen tension was lowered to $6 \%$, hypoxic induction of thrombosis was demonstrated in murine pulmonary vasculature by $8 \mathrm{~h}$ based upon: (a) immunohistologic evidence of fibrin formation in hypoxic lung tissue using an antifibrin antibody, confirmed by $22.5-\mathrm{nm}$ strand periodicity by electron microscopy; $(b)$ immunoblots revealing fibrin gamma-gamma chain dimers in lungs from hypoxic but not normoxic mice or hypoxic mice treated with hirudin; (c) accelerated deposition of ${ }^{125} \mathrm{I}$-fibrin/fibrinogen and ${ }^{111}$ In-labeled platelets in the lung tissue of hypoxic compared with normoxic animals; $(d)$ reduction of tissue ${ }^{125}$ I-fibrin/ fibrinogen accumulation in animals which had either been treated with hirudin or depleted of platelets before hypoxic exposure. Because immunohistochemical analysis of hypoxic pulmonary tissue revealed strong MP staining for TF, confirmed by increased TF RNA in hypoxic lungs, and because ${ }^{111}$ In-labeled murine MPs accumulated in hypoxic pulmonary tissue, we evaluated whether recruited MPs might be responsible for initiation of hypoxia-induced thrombosis. This hypothesis was supported by several lines of evidence: (a) MP depletion before hypoxia reduced thrombosis, as measured by reduced ${ }^{125}$ I-fibrin/fibrinogen deposition and reduced accumulation of cross-linked fibrin by immunoblot; $(b)$ isolated murine MPs demonstrated increased TF immunostaining when exposed to hypoxia; and
\end{abstract}

Address correspondence to Charles A. Lawson, M.D., or David J. Pinsky, M.D., Columbia University, College of Physicians and Surgeons, MHB 4-446, 630 West 168th Street, New York, NY 10032. Phone: 212-305-2575; FAX: 212-305-2182.

Received for publication 15 February 1996 and accepted in revised form 24 January 1997.

J. Clin. Invest.

(C) The American Society for Clinical Investigation, Inc. 0021-9738/97/04/1729/10 \$2.00

Volume 99, Number 7, April 1997, 1729-1738 (c) administration of an anti-rabbit TF antibody that crossreacts with murine TF decreased ${ }^{125}$ I-fibrin/fibrinogen accumulation and cross-linked fibrin accumulation in response to hypoxia in vivo. In summary, these studies using a novel in vivo model suggest that MP accumulation and TF expression may promote hypoxia-induced thrombosis. ( $J$. Clin. Invest. 1997. 99:1729-1738.) Key words: fibrin • tissue factor $\cdot$ monocyte $\cdot$ hypoxia $\cdot$ coagulation

\section{Introduction}

Venous thromboembolism is a major cause of morbidity and mortality, and is associated with major trauma, orthopedic surgery, and limb immobilization $(1,2)$. Lower-extremity venous thrombosis may result in chronic venous insufficiency and is also the precursor of pulmonary embolism that results in 50,000 to 100,000 deaths per year (3). Stasis of blood contributes to thrombi under these conditions, and thrombus formation has been localized to the parietal aspect of venous valve cusps where depositions of platelets, leukocytes, and fibrinlike material have been described (4). Severe hypoxemia has been recorded at this same anatomic site within $2 \mathrm{~h}$ in a canine limb immobilization model (5), and hypoxia has been implicated in the derangement of vascular endothelial anticoagulant properties (6).

Given these associations between hypoxia and thrombosis, we hypothesized that reduced oxygen states might alter the balance of anticoagulant/procoagulant mechanisms in the vasculature to favor activation of coagulation. Although most thrombosis models rely on vascular injury to provide a nidus for clotting (7-9), we have focused on how hypoxia per se may modulate properties of cells of the vascular wall to promote thrombus formation. In this study, we report an in vivo model of whole animal hypoxia, in which hypoxia promotes fibrin formation in the pulmonary vasculature. Our investigation into mechanisms by which hypoxia may trigger thrombosis was prompted by our observation that mononuclear phagocytes $(\mathrm{MPs})^{1}$ accumulated in the lungs during hypoxic exposure, and were associated with the production of tissue factor (TF). Studies were undertaken to examine the possibility that MP accumulation and TF expression underlie the initiation of hypoxia-induced thrombosis. These experiments provide a model for the study of hypoxia-mediated thrombosis, and suggest that MP recruitment and local TF expression are important early events in the prothrombotic diathesis associated with oxygen deprivation.

1. Abbreviations used in this paper: MP, mononuclear phagocyte; PT, prothrombin time; $\mathrm{TF}$, tissue factor. 


\section{Methods}

Induction of hypoxia. In experiments approved by the Columbia University Institutional Animal Care and Use Committee, CD-1 mice (12-15 wk-old; Charles River Laboratories, Wilmington, MA) were subjected to normobaric hypoxic conditions created by the regulated addition of nitrogen to a chamber equipped with circulating fans, carbon dioxide, and ammonia elimination systems, and an on-line oxygen sensor (Horiba Ltd., Kyoto, Japan). The environment within the chamber (including temperature and humidity) was regulated by a custom-built interface ( $\mathrm{K}+\mathrm{K}$ Interface Inc., New York) which used an environmental control program $(\mathrm{K}+\mathrm{K}$ Interface Inc.) running on an XT clone microprocessor equipped with a logic board (model Megaboard; Display Telecommunications Corp., Dallas, TX) and an analogue to digital conversion package (LabMaster Scientific Solutions Inc., Solon, OH). Mice were placed in the chamber in their usual cages and allowed free access to food and water, and the system parameters were adjusted to a final oxygen concentration of 5.5$6.5 \%$. Mice exposed to hypoxia were observed to be tachypneic and have reduced activity, compared with normoxic counterparts. They were exposed to hypoxia for varying times, killed, and tissue was harvested for further analysis. In studies to delineate fibrin formation in lung vasculature, mice received intravenous heparin $(10 \mathrm{U} / \mathrm{g}$, resulting in the APTT $>300 \mathrm{~s}$ ) immediately before killing to limit postmortem clotting. Normoxic control animals (not placed in the chamber) were otherwise treated in the same manner.

Immunohistology. Mice were exposed to hypoxia or normoxia for the indicated durations, tissue was harvested, cut into $10-\mathrm{mm}^{3} \mathrm{sec}-$ tions, washed with PBS, $\mathrm{pH}$ 7.0, to remove blood, fixed in formalin, and embedded in paraffin. Sections were stained with a rabbit antibody raised to rat fibrin monomer which is reactive to fibrin and fibrinogen (anti-rat fibrin IgG, $50 \mu \mathrm{g} / \mathrm{ml}$, provided by Dr. Jef Emeis, Gabius Institute, The Netherlands) (10). Sites of primary antibody binding were visualized with a peroxidase-conjugated secondary antibody, goat anti-rabbit IgG (Sigma Chemical Co., St. Louis, MO).

Electron microscopy. Mouse lung tissue was fixed in $2.5 \%$ glutaraldehyde and sections stained with uranyl acetate and lead. Transmission electron microscopy was performed using a Jeol 100 CX-2 microscope (Jeol, Ltd., Tokyo, Japan).

Immunoblotting. Lung tissue, harvested as above, was placed in buffer (Tris, $0.05 \mathrm{M}, \mathrm{NaCl}, 0.15 \mathrm{M}$, heparin, $500 \mathrm{U} / \mathrm{ml}$, final $\mathrm{pH} 7.6$ ) on ice and homogenized (Brinkmann Instruments, Inc., Westbury, NY). Plasmin digestion was performed by a modification of the methods of Francis (11). Human plasmin (0.32 U/ml, Sigma Chemical Co.) was added to the tissue homogenate, followed by agitation at $37^{\circ} \mathrm{C}$ for $6 \mathrm{~h}$. More plasmin $(0.32 \mathrm{U} / \mathrm{ml})$ was then added, and samples were agitated for an additional $2 \mathrm{~h}$, then the mixture was centrifuged at 2,300 $\mathrm{g}$ for $15 \mathrm{~min}$ and the supernatant aspirated. As a positive control, mouse fibrinogen ( $2.5 \mathrm{mg}$ in $0.25 \mathrm{ml}$; Sigma Chemical Co.) was clotted with human thrombin (4 U; Sigma Chemical Co.) in tris-buffered saline $(1.75 \mathrm{ml})$ in the presence of calcium chloride $(0.013 \mathrm{ml}$ of $2.5 \mathrm{M})$ for $4 \mathrm{~h}$ at room temperature. Clotted fibrinogen was lyophilized, ground into a fine powder with a glass rod, suspended in $1,750 \mu \mathrm{l}$ tris-buffered saline containing human plasmin $(0.32 \mathrm{U} / \mathrm{ml})$ and agitated at $37^{\circ} \mathrm{C}$. Additional plasmin $(0.32 \mathrm{U} / \mathrm{ml})$ was added after $6 \mathrm{~h}$ and samples were agitated for an additional $2 \mathrm{~h}$, after which no visible thrombus was present. As a negative control, unclotted mouse fibrinogen was processed in an identical manner. Samples of plasmin-treated hypoxic and normoxic lung homogenates $(220 \mu \mathrm{g})$, and plasmin-treated clotted and unclotted fibrinogen $(1.7 \mu \mathrm{g})$ were boiled in reducing SDSsample buffer for $5 \mathrm{~min}$, and subjected to SDS-PAGE (10\%; reduced). Samples were electrophoretically transferred to nitrocellulose, and blots were reacted with a polyclonal rabbit anti-human antibody prepared to gamma-gamma chain dimers present in cross-linked fibrin (12) followed by horseradish peroxidase-conjugated goat anti-rabbit IgG (Sigma Chemical Co.). Final detection of bands was performed using the enhanced chemiluminescent Western blotting system (Amersham International, Buckinghamshire, England). Optical density of bands was determined by scanning radiograms with a ScanJet IICX (Hewlett-Packard Co., Palo Alto, CA), linked to a Macintosh 8500 computer (Apple Computer, Inc., Cupertino, CA), with subsequent analysis using NIH Image software.

Accumulation of radioiodinated fibrinogen and $\operatorname{Ig} G$ in the lung. Mouse fibrinogen or mouse nonimmune IgG (Sigma Chemical Co.) were labeled with $\mathrm{Na}^{125}$ ( DuPont NEN, Boston, MA) using the Iodobead method (Pierce Chemical Co., Rockford, IL). The specific radioactivity of tracers was $\sim 10^{4} \mathrm{cpm} / \mathrm{ng}$, and radiolabeled proteins were $>95 \%$ precipitable in $10 \%$ trichloroacetic acid. Animals received 50-200 ng of either ${ }^{125}$ I-labeled fibrinogen or ${ }^{125}$ I-labeled nonimmune $\operatorname{IgG}(2-6 \mu \mathrm{Ci}$ in $0.2 \mathrm{ml}$ saline $)$ via the tail vein. Experiments with hypoxic and normoxic mice, or with hypoxic experimental and hypoxic control mice, were conducted simultaneously using the same batch of labeled protein. At the conclusion of the experiments, mice were treated with heparin, immediately killed, and lungs were harvested, washed, dried, weighed, and assessed for tissue-associated radioactivity. Where indicated, mice were treated with hirudin (13) $(0.5$ $\mathrm{mg} / \mathrm{kg}$ per $\mathrm{h}$ dissolved in saline) or saline alone delivered subcutaneously via osmotic pumps (Alza Corp., Palo Alto, CA) for $8 \mathrm{~h}$ before receiving tail vein injections of ${ }^{125} \mathrm{I}$-fibrinogen followed by hypoxic exposure. The thrombin time (13) in hirudin-treated animals was determined using a kit purchased from Sigma Chemical Co.

Isolation and labeling of mouse platelets, neutrophils (PMNs), and MPs. To assess deposition of platelets, PMNs, and MPs in hypoxic versus normoxic lung, cell populations were isolated, radiolabeled, and infused into mice as follows below.

Platelets were isolated as described (14). In brief, mouse blood obtained by direct cardiac puncture was anticoagulated with $3.7 \%$ sodium citrate and centrifuged at room temperature, first at $300 \mathrm{~g}$ for 5 min to obtain platelet-rich plasma, which was then washed three times with saline and centrifuged at 2,000 $g$ for $15 \mathrm{~min}$. Platelets $(3 \times$ $10^{8}$ ) were resuspended in $1 \mathrm{ml}$ of PBS and incubated under constant agitation with $100 \mu \mathrm{Ci}$ of ${ }^{111} \mathrm{In}$-oxine (Amersham Mediphysics Corp., Arlington Heights, IL) for $30 \mathrm{~min}$ at $37^{\circ} \mathrm{C}$. After labeling, platelets were washed three times with PBS and resuspended in saline; each animal received the ${ }^{111}$ In-labeled platelets by tail vein injection (3-4 $\mu \mathrm{Ci}$ in $0.2 \mathrm{ml}$ ) at the start of each experiment, with mice exposed to normoxia or hypoxia. At the indicated time points, mice were treated with heparin, killed, lungs were harvested, washed, dried and specific activity determined (expressed as cpm/g dry tissue weight).

PMNs and MPs were isolated from mouse blood obtained by direct cardiac puncture in anesthetized mice and anticoagulated with $3.7 \%$ sodium citrate. To obtain PMNs, citrated blood was diluted $1: 1$ with $\mathrm{NaCl}(0.9 \%)$ and subjected to gradient centrifugation at $500 \mathrm{~g}$ on Ficoll-Hypaque (Pharmacia Biotech, Piscataway, NJ) at room temperature for $20 \mathrm{~min}$. After hypotonic lysis of residual erythrocytes (20-s exposure to distilled water and then reconstitution with $1.8 \%$ saline), PMNs ( $>95 \%$ homogeneous cell population) were suspended in HBSS with $5 \mathrm{mg} / \mathrm{ml}$ of BSA (HBSS/A) and were labeled with ${ }^{111} \mathrm{In}-$ oxine using a modification of the method of Zimmerman (15). Approximately $12 \times 10^{6}$ cells, suspended in $2 \mathrm{ml} \mathrm{HBSS} / \mathrm{A}$, were incubated with ${ }^{111} \mathrm{In}$-oxine $\left(0.5 \mu \mathrm{Ci} / 10^{6}\right.$ cells; Amersham Mediphysics Corp.) at $37^{\circ} \mathrm{C}$ for $15 \mathrm{~min}$ under constant agitation. The suspension was centrifuged at $450 \mathrm{~g}$ for $5 \mathrm{~min}$ and the pellet washed twice with HBSS/A, with centrifugation at $450 \mathrm{~g}$ for $5 \mathrm{~min}$. The washed PMN pellet was resuspended in PBS $\left(5 \times 10^{6}\right.$ cells $\left./ \mathrm{ml}\right)$. Each animal received $\sim 8 \times 10^{5}$ PMNs by tail vein injection at the start of experiments. MPs were isolated by density gradient centrifugation as follows. Citrated mouse blood was diluted $1: 1$ with $\mathrm{NaCl}(0.9 \%)$ and $3 \mathrm{ml}$ of this diluted blood was added to an equal volume of Histopaque 1077 (Sigma Chemical Co.), centrifuged at $400 \mathrm{~g}$ for $30 \mathrm{~min}$. The layer of mononuclear cells was aspirated, washed three times with PBS using centrifugation at $250 \mathrm{~g}$ for $10 \mathrm{~min}$. Cell pellets were resuspended in $3 \mathrm{ml}$ RPMI 1640 medium containing 10\% FBS (GIBCO, Grand Island, NY) and plated on 35-mm culture dishes (Becton Dickinson Labware, Lincoln Park, NJ) followed by incubation at $37^{\circ} \mathrm{C}$ for $4 \mathrm{~h}$. After washing twice with PBS, adherent cells were incubated with ${ }^{111}$ In-oxine $\left(0.5 \mu \mathrm{Ci} / 10^{6}\right.$ 
cells; Amersham Mediphysics) in PBS for $15 \mathrm{~min}$ at $37^{\circ} \mathrm{C}$, gently scraped, washed twice with PBS using centrifugation at $250 \mathrm{~g}$ for 10 min, and resuspended in PBS $\left(1 \times 10^{6} \mathrm{cells} / \mathrm{ml}\right)$. Each animal received $\sim 2 \times 10^{5}$ MPs by tail vein injection at the start of experiments. At the indicated time points, mice were treated with heparin, killed, lungs were harvested, and tissue was processed as described for platelets.

Depletion of platelets, PMNs, and MPs. To determine the role of platelets, PMNs and MPs in fibrin formation in hypoxic mouse lung, the effect of antibody-induced depletion of each of these cell types was studied. After depletion of either platelets, PMNs or MPs, the effect on ${ }^{125} \mathrm{I}$-fibrin/fibrinogen incorporation was studied by infusing ${ }^{125}$ I-fibrinogen as described above. The complement activity of antibody-treated animals was compared with standard complement sera by lysis of antibody-sensitized sheep red blood cells using reagents purchased from Sigma Chemical Co.

Platelet depletion was accomplished by administering by tail vein $0.1 \mathrm{ml}$ of either rabbit anti-murine platelet or control sera (Accurate Chemical and Science Corp., Westbury, NY). Platelet counts $16 \mathrm{~h}$ after antiplatelet antisera treatment were $\sim 14,000 / \mu$ l. (Starting value: $100,000 / \mu 1$.) Treatment with control sera resulted in no change in platelet count.

MP or PMN depletion was accomplished using either rabbit antimurine MP or antimurine PMN sera (Accurate Chemical and Science Corp.) $(16,17)$. Animals received daily intraperitoneal injections $(0.3 \mathrm{ml})$ for $3 \mathrm{~d}$. Wright Giemsa-stained peripheral blood smears of anti-MP antibody-treated animals taken $24 \mathrm{~h}$ after injection showed $<1 \%$ circulating MPs; anti-PMN antibody-treated animals displayed absence of PMNs. In contrast, MPs and PMNs were unaffected in control animals.

Expression of TF, and in vitro and in vivo inhibition of TF activity. TF expression was detected in isolated murine MPs and in hypoxic murine lung by immunostaining, and in lung by Northern blotting. To establish that the anti-rabbit TF IgG (18) used for immunostaining blocked tissue factor functional activity, its ability to prolong the prothrombin time (PT) of mouse plasma was assessed. In vivo experiments were then conducted to assess the impact of the antibody on hypoxic pulmonary deposition of ${ }^{125}$ I-fibrin/fibrinogen.

Northern analysis of normoxic and hypoxic mouse lung RNA for TF was performed by first isolating total RNA using the RNA STAT60 procedure (Tel-Test Inc., Friendswood, TX). RNA was subjected to electrophoresis on $0.8 \%$ agarose gels, transferred to nitrocellulose, and hybridized with a cDNA probe for a murine TF (19) or $\beta$-actin (American Type Culture Collection (ATCC), Rockville, MD) at $68^{\circ} \mathrm{C}$ for $1 \mathrm{~h}$. cDNA probes for TF and $\beta$-actin were labeled using random primer labeling (Stratagene Inc., La Jolla, CA). To semiquantitatively assess the strength of the TF bands, the NIH Image computer program was used. Optical density of the TF bands was determined by scanning the radiogram with a Hewlett Packard ScanJet IICX linked to a Macintosh 8500 computer (Hewlett Packard Co., Apple Computer, Inc.), with subsequent analysis using NIH Image software.

Immunoblotting for TF antigen was performed using affinitypurified goat IgG against rabbit TF apoprotein (18) (generously provided by Dr. L.V.M. Rao). The ability of the antibody to cross-react with mouse and rabbit TF apoprotein was assessed by immunoblotting mouse and rabbit brain thromboplastin. Mouse brain thromboplastin was prepared using a modification of the method of Broze (20): the brains from five killed mice were homogenized in $40 \mathrm{ml}$ of ice cold acetone; the slurry was filtered through No. 50 filter paper, dried, and washed in cold acetone and filtered four more times; after drying overnight, the residual powder was suspended in normal saline $(5 \mathrm{~g} / 100 \mathrm{ml})$, heated at $52^{\circ} \mathrm{C}$ for $15 \mathrm{~min}$, and centrifuged $(500 \mathrm{~g}$ for $10 \mathrm{~min}$ ); the supernatant was aspirated and stored at $-20^{\circ} \mathrm{C}$ and used in subsequent assays. Rabbit brain thromboplastin was purchased from Sigma Chemical Co. $20 \mu \mathrm{g}$ of each thromboplastin preparation was subjected to SDS-PAGE (10\% gel), transferred to nitrocellulose, and incubated with the primary antibody $(36 \mu \mathrm{g} / \mathrm{ml})$ for $12 \mathrm{~h}$ at $4{ }^{\circ} \mathrm{C}$ after blocking with $8 \%$ milk protein for $2 \mathrm{~h}$ at room tempera- ture. After washing in PBS with $0.1 \%$ Tween 20 , peroxidase-conjugated anti-goat IgG secondary antibody, $(1 \mu \mathrm{g} / \mathrm{ml}$; Sigma Chemical Co.) was added. Final bands were detected on x-ray film using the enhanced chemiluminescent system (Amersham International).

Immunohistology for TF antigen was performed using the goat IgG against rabbit TF on lung tissue from normoxic or hypoxic animals, with an alkaline phosphatase-conjugated rabbit anti-goat secondary antibody (Sigma Chemical Co.). As a positive control for TF, immunohistochemistry was performed on paraffin-embedded sections of epidermis from normal mice. To determine immunostaining specificity, blocking of goat anti-rabbit TF IgG was accomplished by preincubating the antibody with purified rabbit TF before immunostaining ( $50 \mu \mathrm{l}$ of purified rabbit $\mathrm{TF}[50 \mu \mathrm{g} / \mathrm{ml}]$ incubated overnight at $4^{\circ} \mathrm{C}$ with $1 \mathrm{ml}$ of anti-TF antibody $\left.[9 \mu \mathrm{g} / \mathrm{ml}]\right)$. To confirm the identity of the cells expressing TF, a dual-labeling procedure was employed (21). In this technique, the section was first immunostained with an antibody against the MP antigen, F4/80 (a rat anti-mouse monoclonal antibody (22) (Caltag Laboratories, So. San Francisco, CA) and developed with an alkaline phosphatase-conjugated anti-rat secondary antibody (Sigma Chemical Co.) and photographed. After decolorization, immunostaining for $\mathrm{TF}$ was performed using the goat $\mathrm{IgG}$ against rabbit TF with a horseradish peroxidase-conjugated anti-goat secondary antibody (Sigma Chemical Co.), and the section rephotographed. This technique allows side-by-side comparison of the same tissue section.

Murine MPs were isolated from $12 \mathrm{ml}$ of blood as described previously and resuspended in $16 \mathrm{ml}$ of RPMI 1640 medium containing $10 \%$ FBS (GIBCO). The cell suspension was incubated for $16 \mathrm{~h}$ at $37^{\circ} \mathrm{C}$ on 4 Permanox chamber slide two-well culture chambers (Nunc, Inc., Naperville, IL) and washed three times with PBS to remove nonadherent cells. Serum-free RPMI was then added to the culture chambers and cells were quiescent for $24 \mathrm{~h}$. Cells were then left in the normoxic incubator or placed in a hypoxic incubator $\left(\mathrm{pO}_{2}\right.$ $16 \mathrm{mmHg}$ ) for $16 \mathrm{~h}$, washed with HBSS, and fixed with formalin. Cells were stained with anti-rabbit TF IgG, with sites of primary antibody binding visualized with an alkaline phosphatase-conjugated rabbit anti-goat secondary antibody (Sigma Chemical Co.). To identify the adherent cells as MPs, immunostaining for F4/80 antigen was performed using the rat anti-mouse monoclonal antibody (Caltag Laboratories) and a horseradish peroxidase-conjugated secondary antibody (Sigma Chemical Co.).

In vitro inhibition of TF procoagulant activity using the goat antirabbit TF IgG was assessed by the prothrombin time assay (PT; Sigma Chemical Co.). A standard clotting curve was constructed as follows: mouse brain thromboplastin was serially diluted with normal saline, mixed with an equal volume of $0.02 \mathrm{M}$ calcium chloride (Dade Division, Baxter Corp., Miami, FL) and added to half the volume of citrated mouse plasma, and the time to thrombus formation was measured. All reagents were reacted at $37^{\circ} \mathrm{C}$. A 72 -fold protein excess of either goat anti-rabbit TF IgG or goat nonimmune $\mathrm{IgG}$ was preincubated with the diluted mouse thromboplastin for $1 \mathrm{~h}$ at $37^{\circ} \mathrm{C}$, and the PT was measured. The amount that the clotting time was changed by the addition of anti-TF IgG or nonimmune $\mathrm{IgG}$ was converted to percentage of TF activity from the standard curve, with $100 \% \mathrm{TF}$ activity representing the PT without addition of IgG.

In vivo inhibition of $\mathrm{TF}$ using goat anti-rabbit $\mathrm{TF}$ IgG was assessed by pretreatment of mice (by tail vein injection) with $150 \mathrm{mg} / \mathrm{kg}$ of either goat anti-rabbit TF IgG or goat nonimmune IgG (control), given $2 \mathrm{~h}$ before $16 \mathrm{~h}$ of hypoxic exposure. Tissue was then harvested and analyzed for ${ }^{125}$ I-fibrin/fibrinogen deposition and cross-linked fibrin accumulation, as described.

Statistical analysis. Results are expressed as means \pm SEM with SEM for ratios calculated as described by Cochran (23). Statistical analysis was performed using the Student's two-tailed unpaired $t$ test for comparisons between two groups, using Statview software (Abacus Concepts, Inc., Berkeley, CA). Differences were considered significant if $P \leq 0.05$. 


\section{Results}

Deposition of fibrin, radioiodinated fibrin/fibrinogen, and platelets in hypoxic pulmonary vasculature. Tissue fibrin deposition induced by hypoxic exposure was first demonstrated by immunohistochemistry using a rabbit antibody raised to rat fibrin monomer (10). Staining performed on freshly isolated lung tissue (with antemortem heparin administration to limit postmortem clotting) demonstrated intravascular fibrin deposition as early as $4 \mathrm{~h}$ that became especially evident by $8 \mathrm{~h}$ in hypoxic animals (Fig. $1 A$ ), but not in normoxic controls (Fig. $1 B$ ). Electron microscopy was performed to confirm the presence of fibrin; platelet-associated fibrin demonstrated the characteristic 22.5-nm strand periodicity (24; Fig. 1, $C$ and $D$ ).

Immunoblots of lung tissue extracts were then performed to provide additional confirmation of hypoxia-induced thrombosis. These studies used antibody raised to the gamma-gamma chain dimer present in cross-linked fibrin (12). Extracts of lung
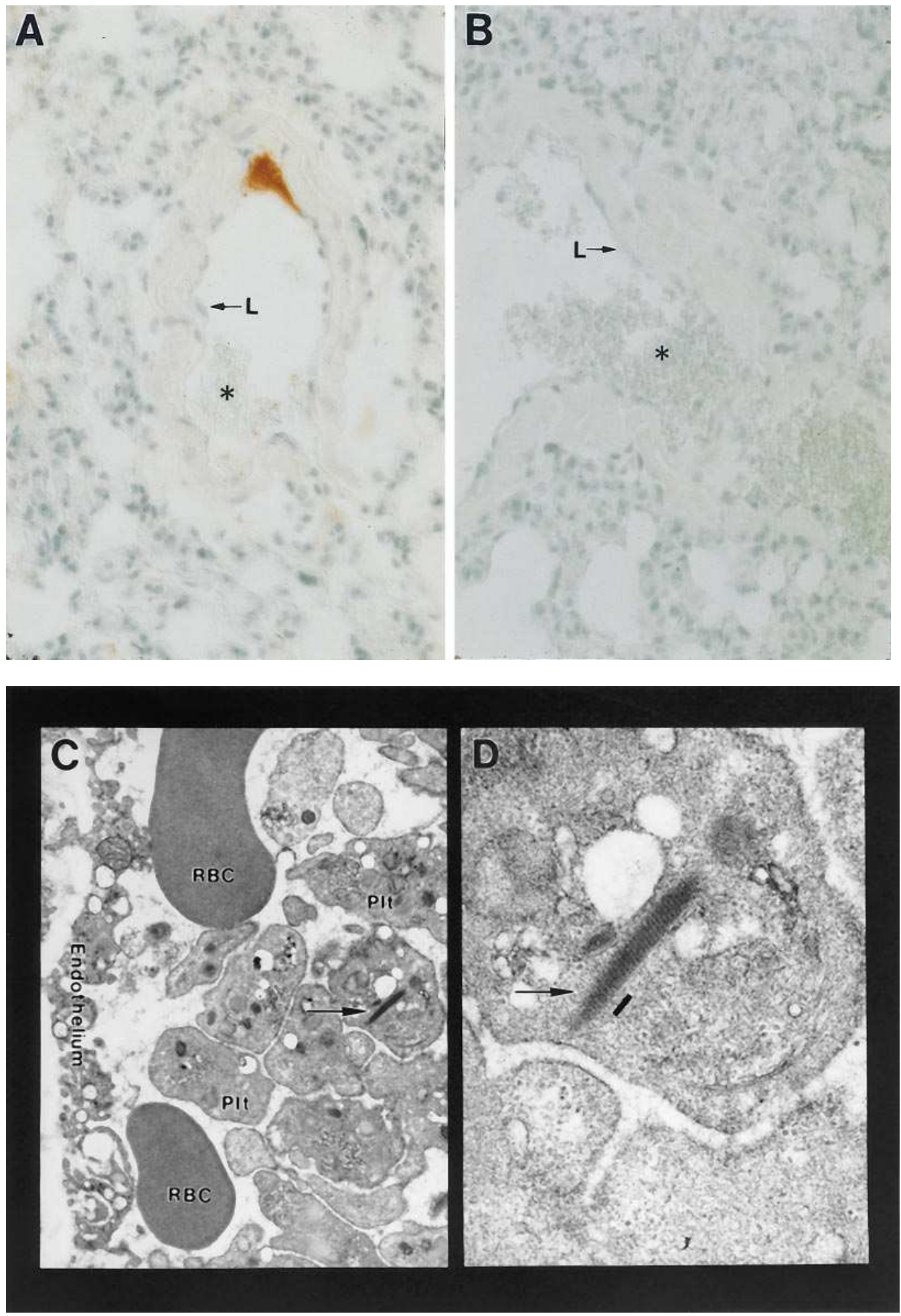

Figure 1. Fibrin deposition in pulmonary vasculature from mice exposed to hypoxia or normoxia. Mice were exposed to hypoxia (A), $\mathrm{FiO}_{2}$ of $\sim 6 \%$, or maintained in normoxia $(B)$ for $8 \mathrm{~h}$, followed by administration of heparin before killing. Tissue was immunostained with antifibrin antibody. $A$ and $B, \times 600$; $(L)$ vascular lumen; (arrows) vascular endothelium; *red blood cells. Experiments with the same concentration of nonimmune serum demonstrated no staining (data not shown). Electron micrograph of hypoxic $(16 \mathrm{~h}) \mathrm{mu}-$ rine pulmonary vasculature (C) showing endothelium, red blood cells $(R B C)$, platelet clumping ( $P l t)$, and platelet-associated fibrin (arrow) Higher magnification $(D)$ demonstrates 22.5 -nm periodicity characteristic of fibrin; black bar, $112 \mathrm{~nm}$. $C, \times 12,450 ; D, \times 44,650$. 


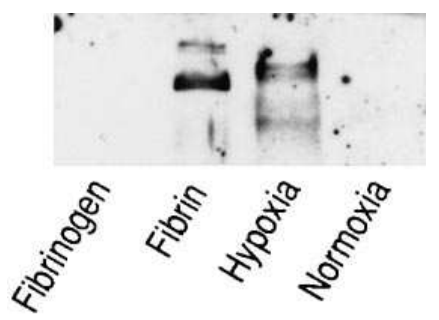

Figure 2. Immunoblotting of lung extracts with antibody to fibrin gamma-gamma chain dimers. Mice were exposed to normoxia $(n=4)$ or hypoxia $(n=4)$ for $16 \mathrm{~h}$ and heparin was administered immediately before killing to prevent postmortem thrombosis. Lung tissue was harvested, washed, homogenized, treated with plasmin as described in the text, and samples were pooled. Other samples consisted of mouse fibrinogen or fibrin, also treated with plasmin. Samples were then solubilized in reducing sample buffer and subjected to reduced SDS-PAGE, transferred to nitrocellulose and immunoblotted with antibody to fibrin gammagamma chain dimers.

were digested with plasmin, and the digest applied to reduced SDS-PAGE. As a positive control for fibrin, murine fibrinogen clotted in vitro and digested by plasmin displayed a similarly migrating band to the hypoxic lung digests (Fig. 2). Densitometric analysis comparing the known amount of fibrin loaded in the fibrin lane with that in hypoxia lane reveals that $\sim 1.2 \mu \mathrm{g}$ of fibrin are present per mg of hypoxic lung tissue. In contrast, plasmin digests of unclotted fibrinogen or normoxic mouse lung demonstrated no discernible bands (Fig. 2, fibrinogen or normoxia lanes, respectively).

As a more rapid and semiquantitative assay for fibrin deposition in hypoxic lung in vivo, accumulation of ${ }^{125} \mathrm{I}$-fibrin/fibrinogen was studied. For these experiments, ${ }^{125} \mathrm{I}$-fibrinogen or ${ }^{125} \mathrm{I}-\mathrm{IgG}$ (control protein) was injected into mice, after which they were randomly separated into normoxic or hypoxic exposure groups for the indicated durations. Accumulation of ${ }^{125} \mathrm{I}-\mathrm{IgG}$ was not different between hypoxic and normoxic tissue up to $16 \mathrm{~h}$ (Fig. 3), though at longer times ( $24 \mathrm{~h}$ and beyond, data not

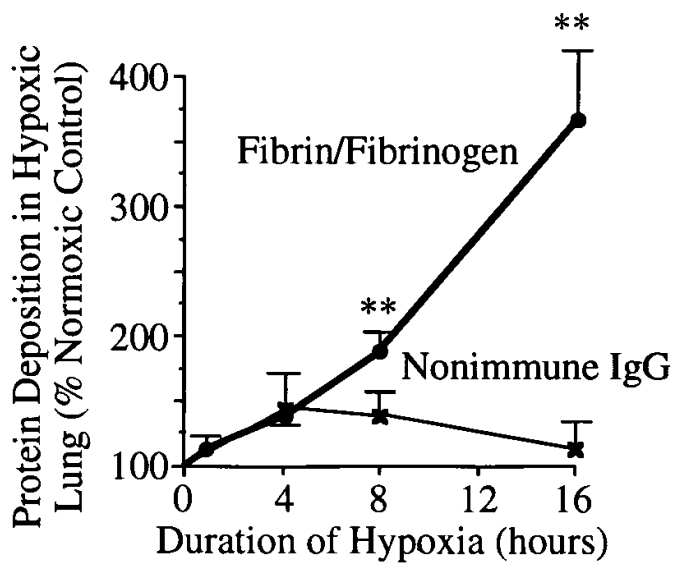

Figure 3. Accumulation of ${ }^{125} \mathrm{I}$-fibrin/fibrinogen in hypoxic lung. Mice were injected via tail vein with either ${ }^{125}$ I-fibrinogen $(n=32)$ or ${ }^{125} \mathrm{I}$-nonimmune $\operatorname{IgG}(n=29)$, killed at the indicated times after exposure to hypoxia or normoxia, and lung tissue was processed as described in the text. Hypoxic and normoxic animals at each time point received identical amounts of the labeled protein. Data are graphed as the percent of normoxic control which is the ratio of $\mathrm{cpm} / \mathrm{g}$ dry tissue in hypoxic versus normoxic animals $(100 \%=$ same amount of radioactivity in hypoxic and normoxic tissue per g). ${ }^{* *} P<0.01$ for hypoxic versus normoxic $\mathrm{cpm} / \mathrm{g}$.

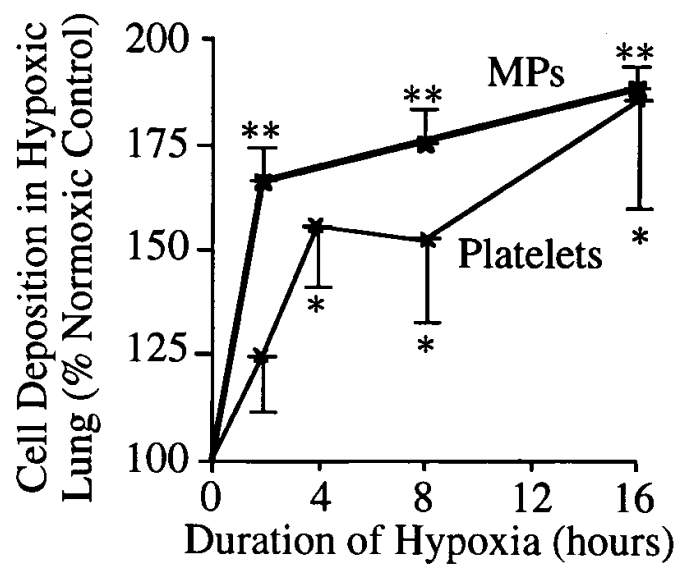

Figure 4. Deposition of ${ }^{111} \mathrm{In}$-labeled cells in hypoxic lung. Mice were injected via tail vein with either ${ }^{111}$ In-labeled murine platelets $(n=$ $36)$ or MPs $(n=22)$, and killed at the indicated times after exposure to hypoxia or normoxia. Lung tissue was processed as described in the text. Hypoxic and normoxic animals at each time point received identical amounts of the labeled cells. Data are graphed as the percent of normoxic control which is the ratio of $\mathrm{cpm} / \mathrm{g}$ dry tissue in hypoxic versus normoxic animals $(100 \%=$ same amount of radioactivity in hypoxic and normoxic tissue per g). $* P<0.05$ and $* * P<0.01$ for hypoxic versus normoxic $\mathrm{cpm} / \mathrm{g}$.

shown) there was an increase in IgG deposition, consistent with increased vascular permeability on prolonged exposure to oxygen deprivation (25). In contrast, there was a steady rise in ${ }^{125}$ I-fibrin/fibrinogen in the hypoxic lung versus normoxic controls (Fig. 3; cpm/g in hypoxic/normoxic lung tissue at 1, 4, 8, and $16 \mathrm{~h}$, respectively, were $5.0 \times 10^{4} \pm 6.6 \times 10^{3} / 4.5 \times 10^{4} \pm 3.7 \times$ $10^{3}, 5.8 \times 10^{4} \pm 7.2 \times 10^{3} / 4.2 \times 10^{4} \pm 1.2 \times 10^{4}, 3.2 \times 10^{4} \pm 2.1 \times$ $10^{3} / 1.7 \times 10^{4} \pm 2.1 \times 10^{3}, 2.8 \times 10^{4} \pm 2.3 \times 10^{3} / 7.7 \times 10^{3} \pm 7.3 \times$ $10^{2}$, respectively). In addition, ${ }^{111}$ In-labeled platelets accumulated in hypoxic lung in a time-dependent manner versus normoxic controls (Fig. 4; cpm/g in hypoxic and normoxic lung at $2,4,8$, and $16 \mathrm{~h}$, respectively, were $2.2 \times 10^{4} \pm 2.5 \times 10^{3} / 1.8 \times$ $10^{4} \pm 4.8 \times 10^{2}, 2.4 \times 10^{4} \pm 1.2 \times 10^{3} / 1.5 \times 10^{4} \pm 2.0 \times 10^{3}, 1.1 \times$ $10^{4} \pm 1.1 \times 10^{3} / 7.3 \times 10^{4} \pm 5.5 \times 10^{2}, 1.8 \times 10^{4} \pm 1.1 \times 10^{3} / 9.3 \times$ $10^{3} \pm 1.7 \times 10^{3}$, respectively).

Further evidence confirming that activation of coagulation was responsible for accumulation of ${ }^{125} \mathrm{I}$-fibrin/fibrinogen and cross-linked fibrin in hypoxic murine lung was derived from studies with the thrombin inhibitor hirudin (13). Mice pretreated with hirudin at a dose which increased thrombin time from 18 to $50 \mathrm{~s}$ demonstrated inhibition of hypoxic ${ }^{125}$ I-fibrin/ fibrinogen deposition (Fig. $5 A$ ) and a decrease in the Western blotting signal for fibrin gamma-gamma dimer (Fig. $5 \mathrm{~B}$ ). To evaluate whether platelets, which provide a major amplification mechanism for activation of the procoagulant pathway, also participate in hypoxia-induced thrombosis, the effect of platelet depletion on hypoxia-induced ${ }^{125}$ I-fibrin/fibrinogen accumulation was examined. Platelet depletion reduced pulmonary ${ }^{125}$ I-fibrin/fibrinogen accumulation (Fig. $5 A$ ).

Involvement of PMNs and MPs in hypoxia-induced accumulation of radioiodinated fibrin/fibrinogen in hypoxic lung. To explore potential mechanisms which might initiate hypoxia-induced thrombosis, we examined the roles of other circulating cell types in addition to platelets. For these studies, we used a strategy of depleting certain cell populations and exam- 

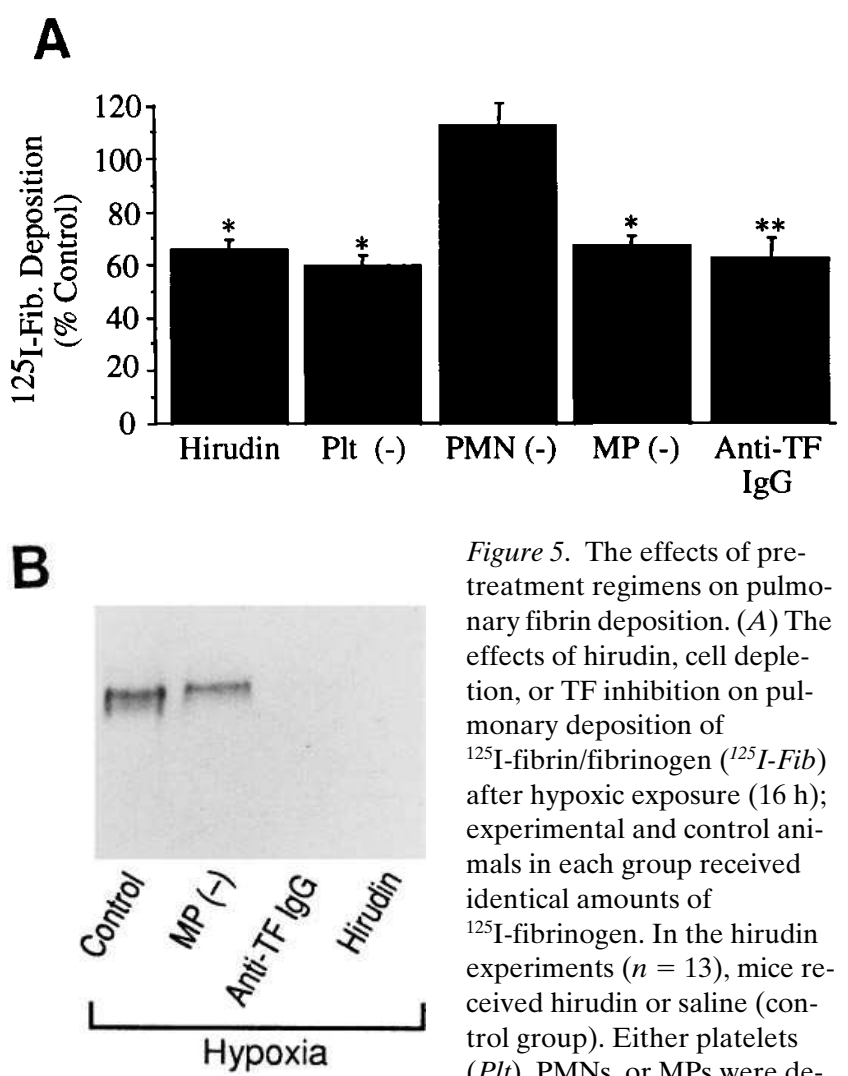

Figure 5. The effects of pretreatment regimens on pulmonary fibrin deposition. $(A)$ The effects of hirudin, cell depletion, or TF inhibition on pulmonary deposition of ${ }^{125}$ I-fibrin/fibrinogen $\left({ }^{125} \mathrm{I}\right.$-Fib) after hypoxic exposure $(16 \mathrm{~h})$; experimental and control animals in each group received identical amounts of ${ }^{125}$ I-fibrinogen. In the hirudin experiments $(n=13)$, mice re ceived hirudin or saline (control group). Either platelets (Plt), PMNs, or MPs were depleted $(-)$ with specific antisera, with controls receiving the identical dose of nonimmune sera ( $n=9,8$, and 8, for Plt, PMN, and MP experiments, respectively). TF was inhibited by goat anti-rabbit TF $\operatorname{IgG}($ Anti-TF $\operatorname{Ig} G)$ administration, with control animals receiving goat nonimmune IgG (Nonimmune $\mathrm{IgG} ; n=11$ for TF inhibition experiments). Data are graphed as the percent of control which is the ratio of $\mathrm{cpm} / \mathrm{g}$ dry tissue in treated versus control animals. $* P<0.05$ and $* * P<0.01$ for treated versus control cpm/g. (B) Using identical pretreatment regimens as in the ${ }^{125} \mathrm{I}$-fibrin/fibrinogen experiments above, the presence of fibrin gamma-gamma chain dimers was assessed in animals treated with hirudin, anti-TF antibody (Anti-TF IgG), or depleted of MPs (with nonimmune sera serving as a control). The figure shows blotting from a representative animal in each treatment group.

ining the impact on hypoxic ${ }^{125}$ I-fibrin/fibrinogen deposition. Because of previous studies indicating that hypoxia promotes tissue leukostasis (26), probably through multiple mechanisms, we considered the possibility that PMNs drawn into hypoxic lung might become activated, damage the endothelium, and expose underlying TF. ${ }^{111} \mathrm{In}$-labeled PMN accumulation significantly increased in hypoxic lung compared with normoxic controls at 8 and $16 \mathrm{~h}(225 \pm 30 \%, 500 \pm 50 \%$, respectively; $n=$ $19, P<0.01$ for each time point). Although mice were rendered profoundly neutropenic before hypoxic exposure (platelets and MPs were not reduced on peripheral blood smear), hypoxia-induced ${ }^{125}$ I-fibrin/fibrinogen accumulation in lung remained unaltered (Fig. $5 \mathrm{~A}$ ).

MPs have the potential to express TF, suggesting that they may play a role in thrombotic processes $(27,28)$. Murine MPs labeled with ${ }^{111}$ In were arrested in hypoxic lung, compared with normoxic counterparts (Fig. 4), as early as $2 \mathrm{~h}$ after the initiation of hypoxic exposure. The possible contribution of
MPs to ${ }^{125}$ I-fibrin/fibrinogen deposition and cross-linked fibrin formation in hypoxic lung was suggested by studies in which MPs were depleted before hypoxic exposure (peripheral blood smears confirmed $<1 \%$ MPs after antibody administration) (16). In MP-depleted animals, hypoxic deposition of ${ }^{125}$ I-fibrin/ fibrinogen and Western blot fibrin gamma-gamma dimer signal were reduced 35 and $65 \%$, respectively (Fig. 5, $A$ and $B$ ).

Expression of TF in hypoxic lung and by hypoxic MPs. Because the data suggested that MPs participate in hypoxiainduced thrombosis, and because MPs are a known source of TF $(27,28)$, we investigated whether hypoxia could trigger TF expression in MPs in vitro or in the lung in vivo.

The ability of goat anti-rabbit TF IgG (18) to cross-react with murine TF established suitability of using this antibody in a murine system. Immunoblotting with mouse brain thromboplastin and rabbit brain thromboplastin preparations (sources of TF) demonstrated comigrating bands of similar molecular weights $(18,19$, 29; Fig. 6 A). Mouse epidermis, normally high in TF, exhibited an intense signal when goat anti-rabbit TF IgG was used for immunostaining (Fig. $6 \mathrm{~B}$ ); the signal was markedly diminished by preincubating the antibody with purified rabbit TF (Fig. $6 C$ ). The ability of goat anti-rabbit TF $\mathrm{IgG}$ to block TF procoagulant activity was assessed using the prothrombin time, a measure of TF-dependent clotting. Preincubation of murine thromboplastin with goat anti-rabbit TF $\mathrm{IgG}$ resulted in prolongation of the PT equal to a $70 \%$ reduction in TF activity (Fig. $6 D$ ).

Next, expression of TF was studied in lung harvested from hypoxic mice. Northern analysis demonstrated a 4.7-fold increase in TF RNA, quantified with NIH Image software, whereas $\beta$-actin transcripts were unchanged, after $4 \mathrm{~h}$ of hypoxia (Fig. $7 \mathrm{~A}$ ). Immunostaining using goat anti-rabbit TF IgG showed enhanced antigen expression in hypoxic murine lung, compared with normoxic controls (Fig. 7, $B$ and $C$ ). Increased TF staining in hypoxic lung (Fig. $7 E$ ) occurred in cells staining for the MP antigen, F4/80 (Fig. $7 \mathrm{D}$ ). In addition, animals made deficient in circulating monocytes displayed less pulmonary TF expression than controls (data not shown). To confirm that murine MPs increase expression of TF when deprived of oxygen, MPs isolated from murine blood (staining for F4/80 antigen; Fig. $7 H$ ) and exposed to hypoxia showed enhanced TF immunostaining (Fig. $7 G$ ) compared with normoxic MPs (Fig. 7 F). Having established that goat anti-rabbit TF IgG has functional in vitro TF blocking ability (Fig. $7 \mathrm{D}$ ), we used it to investigate hypoxia-induced thrombosis in vivo, as measured by ${ }^{125} \mathrm{I}$-fibrin/fibrinogen deposition and crosslinked fibrin formation in hypoxic lung. Mice pretreated before hypoxic exposure with goat anti-rabbit TF $\mathrm{IgG}$, but not nonimmune $\operatorname{IgG}$, had a $39 \%$ suppression of ${ }^{125} \mathrm{I}$-fibrin/fibrinogen accumulation (Fig. $5 \mathrm{~A}$ ) and a $95 \%$ reduction of the fibrin gamma-gamma dimer signal by Western blot (Fig. $5 \mathrm{~B}$ ). Additional studies demonstrated the half-life of elimination of ${ }^{125}$ I-labeled anti-TF IgG in mice to be $\sim 53 \mathrm{~h}$, consistent with previous measurements of $\operatorname{IgG}$ injected into mice (30).

\section{Discussion}

In the 1850 s, Virchow linked venous thrombosis to hypercoagulability, vascular damage, and stasis (31). In recent years, nonpulsatile flow resulting in stasis has been associated with rapid intravascular hypoxemia, white blood cell margination, and thrombus formation in veins of the lower extremities $(4,5)$. 
A

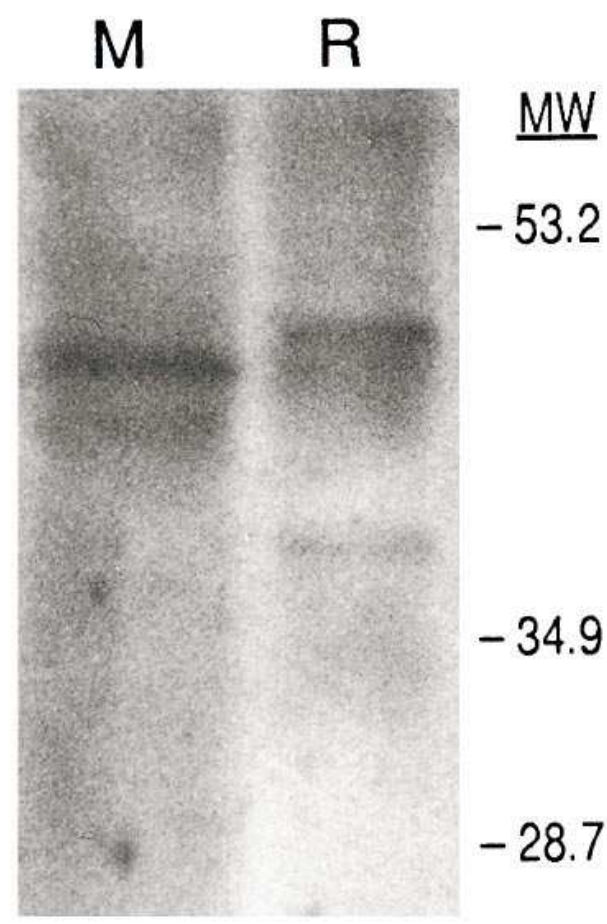

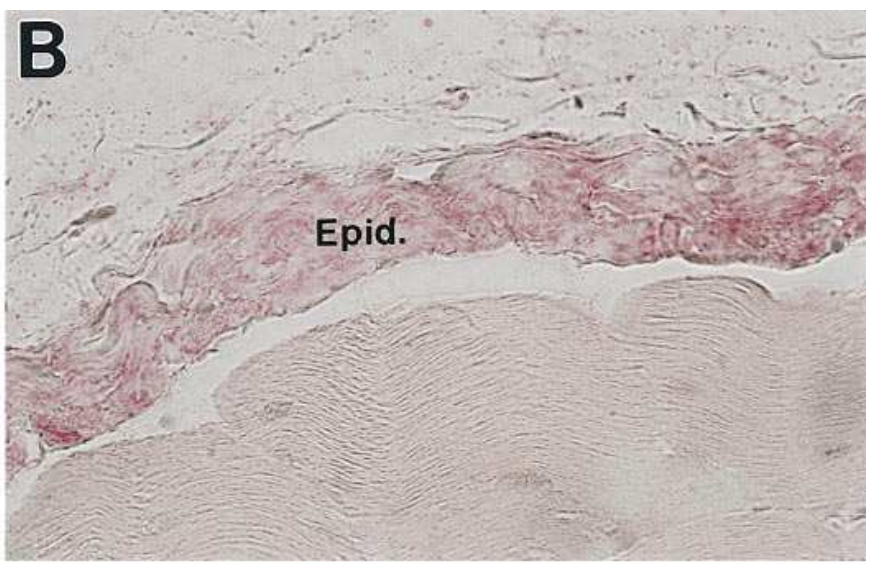

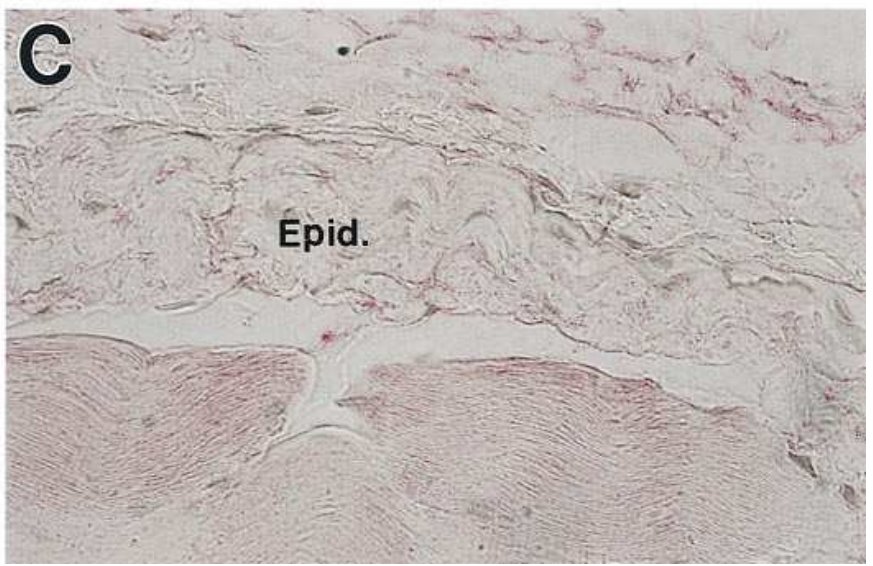

\section{D}

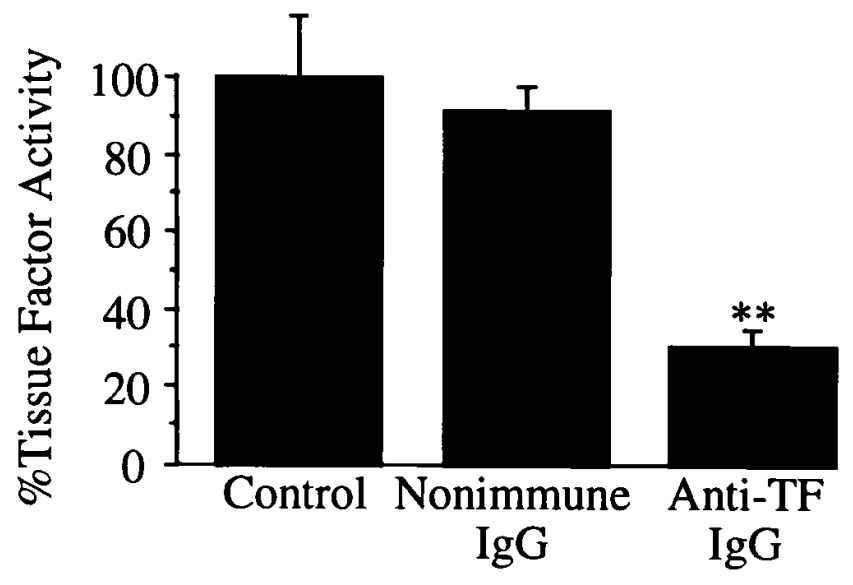

These observations, taken together with our previous findings that hypoxia decreased expression of the anticoagulant cofactor thrombomodulin (6), suggested that oxygen deprivation per se might result in a prothrombotic diathesis. In view of the continuing clinical importance of venous thromboembolism, especially in certain high-risk patients (1), we sought to develop an in vivo model allowing investigation of pathophysiologic mechanisms underlying hypoxia-associated thrombosis.

At the outset, we speculated that hypoxia would modulate endothelial properties directly, promoting development of the prothrombotic state. Shatos et al. (32) observed changes in ex-
Figure 6. Cross-reactivity of goat anti-rabbit TF IgG. (A) Cross-reactivity of the goat anti-rabbit TF IgG for murine and rabbit TF is demonstrated by comigrating bands of similar molecular weights for mouse $(M)$ and rabbit $(R)$ brain thromboplastin. Preincubation of anti-rabbit TF IgG with purified rabbit TF blocked visualization of the bands (data not shown). (B) TF in murine epidermis (Epid) is visualized by immunostaining (red) with goat anti-rabbit TF IgG. No staining was seen using goat nonimmune $\operatorname{IgG}$ (data not shown). (C) Blocking was achieved by preincubation with purified rabbit TF. $(D)$ The ability of goat anti-rabbit TF IgG (Anti-TF IgG) to inhibit in vitro TF-dependent coagulation, as assessed by prolongation of the prothrombin time, was compared to the effect of goat nonimmune IgG (Nonimmune $\operatorname{Ig} G$ ). Data are graphed as percent of TF activity, with $100 \%$ activity representing the baseline PT. ** $P<0.01$ for Anti-TF IgG versus Nonimmune IgG percentage of TF activity. $B, C \times 200$.

pression of fibrinolytic components. However, in those experiments with ECs, the small increase in plasminogen activator inhibitor-1 and plasminogen activators did not appear to be potent factors promoting fibrin deposition. Similarly, our earlier experiments demonstrating hypoxic suppression of endothelial thrombomodulin at the mRNA, antigen, and activity levels, occurred only after $24 \mathrm{~h}$, whereas fibrin deposition in this study was observed within $4-8 \mathrm{~h}$. Further experiments with hypoxic ECs failed to show induction of TF, though at later times, activation of Factor $\mathrm{X}$ (independent of TF) was observed (6). Because ECs exposed to hypoxia express P-selectin 

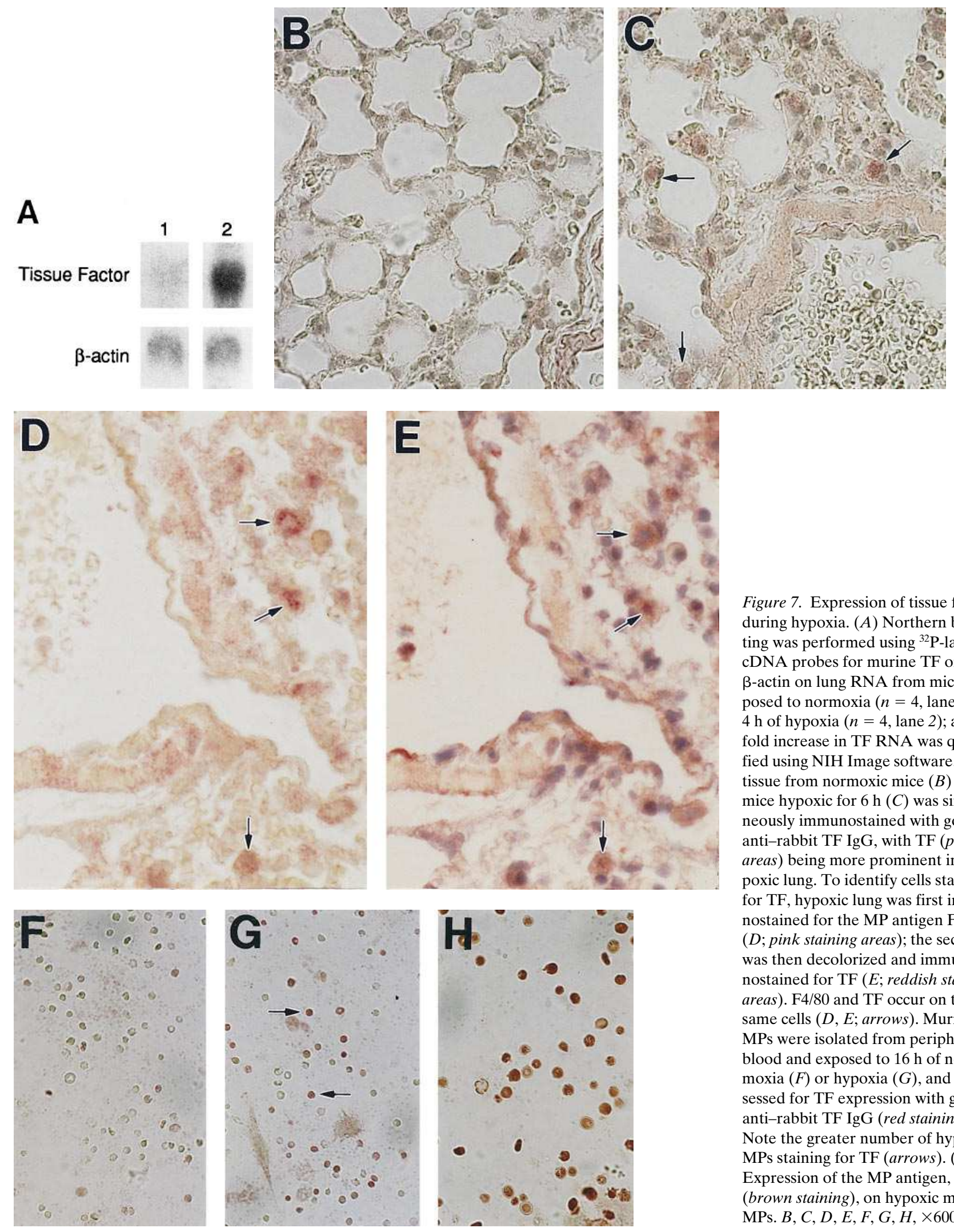

Figure 7. Expression of tissue factor during hypoxia. $(A)$ Northern blotting was performed using ${ }^{32} \mathrm{P}$-labeled cDNA probes for murine TF or $\beta$-actin on lung RNA from mice exposed to normoxia $(n=4$, lane 1$)$ or 4 h of hypoxia $(n=4$, lane 2$)$; a 4.7 fold increase in TF RNA was quantified using NIH Image software. Lung tissue from normoxic mice $(B)$ and mice hypoxic for $6 \mathrm{~h}(C)$ was simultaneously immunostained with goat anti-rabbit TF IgG, with TF (pink areas) being more prominent in hypoxic lung. To identify cells staining for $\mathrm{TF}$, hypoxic lung was first immunostained for the MP antigen F4/80 ( $D$; pink staining areas); the section was then decolorized and immunostained for TF ( $E$; reddish staining areas). $\mathrm{F} 4 / 80$ and $\mathrm{TF}$ occur on the same cells $(D, E$; arrows). Murine MPs were isolated from peripheral blood and exposed to $16 \mathrm{~h}$ of normoxia $(F)$ or hypoxia $(G)$, and assessed for TF expression with goat anti-rabbit TF IgG (red staining). Note the greater number of hypoxic MPs staining for TF (arrows). $(H)$ Expression of the MP antigen, F4/80 (brown staining), on hypoxic murine MPs. $B, C, D, E, F, G, H, \times 600$.

(33), IL-8 (26), synthesize platelet-activating factor (PAF) (34), and express intercellular adhesion molecule-1 (ICAM-1) (34) resulting in enhanced adhesivity of hypoxic endothelium for leukocytes and subsequent PMN activation (34), we first investigated whether PMN recruitment might underlie hypoxia-induced thrombosis. Experimental data in our model showed that ${ }^{111}$ In-labeled PMNs deposited in hypoxic lung, but that ${ }^{125} \mathrm{I}$-fibrin/fibrinogen accumulation was not affected in 
neutropenic mice. This suggested that accumulated PMNs were unlikely to mediate early events in the pathogenesis of fibrin deposition associated with oxygen deprivation.

In contrast to PMNs, however, MP recruitment appeared to be involved in the pathogenesis of fibrin formation, as animals deficient in MPs exhibited reduced ${ }^{125} \mathrm{I}$-fibrin/fibrinogen and cross-linked fibrin accumulation under hypoxic conditions. Further studies showed that TF expression by recruited MPs was likely to underlie initiation of hypoxia-induced fibrin deposition. These data lead us to propose a scenario in which MPs are recruited into hypoxic lung, become activated, and express TF which promotes fibrin formation. Platelets also accumulate, amplifying the thrombotic process. In support of our concept that MPs contribute to pathologic fibrin formation associated with hypoxia, we have also found that hypoxic MPs also synthesize increased amounts of a key inhibitor of the fibrinolytic pathway, plasminogen activator inhibitor-1 (PAI-1) (35). Monocyte regulation of coagulation in hypoxia is consistent with previous data that suggest an active role for MPs in other aspects of the physiologic/pathophysiologic response to oxygen deprivation, such as elaboration of angiogenic factors $(36,37)$. Whereas others have shown that TF plays an important role in pulmonary fibrin deposition in response to injury (38), in our model, hypoxia alone was a sufficient stimulus for $\mathrm{TF}$ induction. Interference with hypoxic MP recruitment or TF expression in vivo, either by decreasing the number of MPs, or by blocking TF with anti-TF IgG, resulted in decreased thrombosis, as measured by hypoxia-induced ${ }^{125}$ I-fibrin/fibrinogen and cross-linked fibrin accumulation. These data support observations demonstrating induction of TF in alveolar macrophages in lung subjected to ischemic preservation (39).

Although it is possible that our experimental method of MP depletion (immunodepletion) may have affected more than one cell type, this was not evident on peripheral smears. In addition, complement activity in the MP- and PMN-depleted animals was normal (data not shown). PMNs, though having an identified role in platelet interaction (40), and accumulating later on in hypoxic lung tissue in our experiments, do not appear to be involved in the initiation of hypoxia-induced thrombosis. The ability of hirudin, platelet or MP depletion, and anti-TF antibody administration to only partially suppress ${ }^{125}$ I-fibrin/fibrinogen deposition, but more fully inhibit crosslinked fibrin accumulation (measured by Western blotting for gamma-gamma dimer) suggests that there is high background signal present in the ${ }^{125} \mathrm{I}$-fibrin/fibrinogen assay. Distinguishing intravascular from extravascular sites of thrombosis using whole-lung assays ( ${ }^{125} \mathrm{I}$-fibrin/fibrinogen deposition and Western blotting for gamma-gamma dimer) is complicated by the potentially procoagulant environment of the alveolar space. However, in the current experiments, immunohistology demonstrates that there is intravascular fibrin formation in this model.

One potential experimental limitation involves the need to use living animals in this model of hypoxia-induced thrombosis. As with any in vivo model, it is possible that oxygen deprivation might foster systemic cytokine activation, and enhanced TF expression in circulating MPs as well as extravascular cells. In the same light, MPs themselves could also indirectly induce $\mathrm{TF}$ expression elsewhere in the lung through the elaboration of mediators. Our results, therefore, may reflect both local and systemic factors. To examine the effect of whole animal hypoxia on impaired intestinal barrier function (which could in- crease systemic exposure to endotoxins and complicate local findings of TF production), plasma from mice exposed to $16 \mathrm{~h}$ of hypoxia $(n=3)$ and normoxia $(n=3)$ was assayed for endotoxin by the Limulus amebocyte lysate method (41) (E-Toxate; Sigma Chemical Co.). In both groups of mice, endotoxin was undetectable, indicating that the duration and degree of hypoxia used in these experiments did not result in endotoxinemia within the detection limits of the assay $(0.06 \mathrm{EU} / \mathrm{ml})$.

This in vivo model of hypoxia-induced thrombosis might constitute a useful method for evaluating transgenic and knockout mice with alterations in the coagulation system (42-44). Our hypothesis to explain early fibrin formation in settings of oxygen deprivation raises important questions concerning underlying mechanisms. How are MPs recruited into hypoxic loci? By what means does oxygen deprivation increase TF? What other factors in hypoxic and ischemic microenvironments prime the procoagulant pathway and/or suppress natural antithrombotic mechanisms? Answers to these questions will provide critical tests of our hypothesis and provide new insights to delineate hypoxia-inducible mechanisms promoting fibrin formation in a range of ischemic conditions.

\section{Acknowledgments}

We thank Dr. O. Chappey for calculating anti-TF IgG disposition parameters, and Dr. Gabriel Godman for helpful advice and suggestions. Dr. Pinsky performed this work during the tenure of a Clinician-Scientist Award from the American Heart Association.

This research was supported by a Foundation for Anesthesia Education and Research Young Investigator Award through a grant from Mallinckrodt Anesthesiology (C.A. Lawson), U.S. Public Health Service grants HL55397, (D.J. Pinsky), HL35246, (W. Kisiel), and HL50629 and HL42507, (D.M. Stern), and by grants from the American Heart Association and the Cystic Fibrosis Foundation (D.J. Pinsky).

\section{References}

1. Geerts, W.H., K.I. Code, R.M. Jay, E. Chen, and J.P. Szalai. 1994. A prospective study of venous thromboembolism after major trauma. N. Engl. J. Med. 331:1601-1606.

2. Anderson, F.A., Jr., H.B. Wheeler, R.J. Goldberg, D.W. Hosmer, N.A. Patwardhan, B. Jovanovic, A. Forcier, and J.E. Dalen. 1991. A populationbased perspective of the hospital incidence and case-fatality rates of deep vein thrombosis and pulmonary embolism. Arch. Intern. Med. 151:933-938.

3. Coon, W.W. 1977. Epidemiology of venous thromboembolism. Ann. Surg. 186:149-154.

4. Malone, P.C., and C.J. Morris. 1978. The sequestration and margination of platelets and leukocytes in veins during conditions of hypokinetic and anaemic hypoxia: potential significance in clinical postoperative venous thrombosis. J. Pathol. 125:119-129.

5. Hamer, J.D., P.C. Malone, and I.A. Silver. 1981. The pO2 in venous valve pockets: its possible bearing on thrombogenesis. Br. J. Surg. 68:166-170.

6. Ogawa, S., H. Gerlach, C. Esposito, A. Pasagian-Macauley, J. Brett, and

D. Stern. 1990. Hypoxia modulates the barrier and coagulant function of cultured bovine endothelium. J. Clin. Invest. 85:1090-1098.

7. Folts, J.D., E.B. Crowell, and G.G. Rowe. 1976. Platelet aggregation in partially observed vessels and its elimination with aspirin. Circulation. 54:365-370.

8. Yasuda, T., H.K. Gold, J.T. Fallon, R.C. Leinbach, H.D. Garabedian, J.L. Guerro, and D. Collen. 1989. A canine model of coronary artery thrombosis with superimposed high grade stenosis for the investigation of rethrombosis after thrombolysis. J. Am. Coll. Cardiol. 13:1409-1414.

9. Romson, J.L., D.W. Haack, and B.R. Lucchesi. 1980. Electrical induction of coronary artery thrombosis in the ambulatory canine: a model for in vivo evaluation of anti-thrombotic agents. Thromb. Res. 17:841-853.

10. Emeis, J.J., J. Lindeman, and W. Nieuwenhuizen. 1981. Immunoenzyme histochemical localization of fibrin degradation products in tissues. Am. J. Pathol. 103:337-344.

11. Francis, C.W., V.J. Marder, and S.E. Martin. 1980. Plasmic degradation of cross-linked fibrin I. Structural analysis of the particulate clot and identification of new macromolecular-soluble complexes. Blood. 56:456-464. 
12. Lahiri, B., J.A. Koehn, R.E. Canfield, S. Birken, and J. Lewis. 1981. Development of an immunoassay for the $\mathrm{COOH}$-terminal region of the gamma chains of human fibrin. Thromb. Res. 23:103-112.

13. Markwardt, F. 1991. Hirudin and its derivatives as anticoagulant agents. Thromb. Haemostasis. 66:141-152.

14. Naka, Y., N.C. Chowdhury, H. Liao, D.K. Roy, M.C. Oz, R.E. Micheler, and D.J. Pinsky. 1995. Enhanced preservation of orthotopically transplanted rat lungs by nitroglycerin but not hydralazine: requirement for graft vascular homeostasis beyond harvest vasodilation. Circ. Res. 76:900-906.

15. Zimmerman, G.A., T.M. McIntyre, and S.M. Prescott. 1985. Thrombin stimulates the adherance of neutrophils to human endothelial cells in vitro. $J$. Clin. Invest. 76:2235-2246.

16. Unanue, E.R. 1968. Properties and some uses of anti-macrophage antibodies. Nature (Lond.). 218:36-38.

17. Connolly, E.S., C.J. Winfree, T.A. Springer, Y. Naka, H. Liao, S.D. Yan, D.M. Stern, R.A. Solomon, J.-C. Gutierrez-Ramos, and D.J. Pinsky. 1996. Cerebral protection in homozygous null ICAM-1 mice after middle cerebral artery occlusion. Role of neutrophil adhesion in the pathogenesis of stroke. J. Clin. Invest. 97:209-216.

18. Rao, L.V.M., and A.D. Hoang. 1989. Purification and characterization of rabbit tissue factor. Thromb. Res. 56:109-118.

19. Hartzell, S., K. Ryder, A. Lanahan, L.F. Lau, and D. Nathans. 1989. A growth factor-responsive gene of murine BALB/c 3 T3 cells encodes a protein homologous to human tissue factor. Mol. Cell Biol. 9:2567-2573.

20. Broze, G.J., J.E. Leykam, B.D. Schwartz, and J.P. Miletich. 1985. Purification of human brain tissue factor. J. Biol. Chem. 260:10917-10920.

21. Yan, S.D., X. Chen, A.M. Schmidt, J. Brett, G. Godman, Y.S. Zou, C.W. Scott, C. Caputo, T. Frappeir, M.A. Smith, et al. 1994. Glycated tau protein in Alzheimer disease: A mechanism for the induction of oxidant stress. Proc. Natl. Acad. Sci. USA 91:7787-7791.

22. Lee, S.-H., P.M. Starky, and S. Gordon. 1985. Quantitative analysis of total macrophage content in adult mouse tissues. J. Exp. Med. 161:475-489.

23. Cochran, W.G. 1977. Sampling techniques. John Wiley \& Sons, Inc., New York. 30 pp.

24. Weisel, J.W. 1986. The electron microscope band pattern of human fibrin: various stains, lateral order, and carbohydrate localization. J. Ultrastruct. Mol. Struct. Res. 96:176-188.

25. Ogawa, S., R. Shreeniwas, J. Brett, M. Clauss, M. Furie, and D.M. Stern. 1990. The effect of hypoxia on capillary endothelial cell function: modulation of barrier and coagulant function. Br. J. Haematol. 76:517-524.

26. Karakurum, M., R. Shreeniwas, J. Chen, D.J. Pinsky, J. Sunouchi, T. Hamilton, M. Anderson, K. Kuwabara, A. Rot, R. Nowygrod, et al. 1994. Hypoxic induction of Interleukin-8 gene expression in endothelial cells. J. Clin. Invest. 93:1564-1570.

27. Edwards, R.L., F.R. Rickles, and A.M. Bobrove. 1979. Mononuclear cell tissue factor: cell of origin and requirements for activation. Blood. 54:359370 .

28. Gregory, S.A., and T.S. Edgington. 1985. Tissue factor induction in human monocytes: two distinct mechanisms displayed by different alloantigenresponsive T-cell clones. J. Clin. Invest. 76:2440-2445.

29. Andrews, B.S., A. Rehemtulla, B.J. Fowler, T.S. Edgington, and N. Mackman. 1991. Conservation of tissue factor primary sequence among three mammalian species. Gene. 98:265-269.

30. Zhu, Z., G. Tarunendu, S. Iles, C. Yang, S.H.S. Lee, L.A. Fernandez, and C.L.Y. Lee. 1994. Pharmacokinetics, biodistribution, and tumor localiza- tion of two anti-human B-Cell chronic lymphocytic leukemia monoclonal antibodies and their F(ab)' ${ }_{2}$ fragments in a xenograft model. Cancer Lett. 76:31-44.

31. Virchow, R. 1856. Gessamelte Abhandlungen zur Wissenschaftlichen Medicin. A.M. Von Meidinger Sohn and Co., Frankfurt, Germany. 525 pp.

32. Shatos, M.A., J.M. Doherty, T. Orfeo, J.C. Hoak, D. Collen, and D.C. Stump. 1992. Modulation of the fibrinolytic response of cultured human vascular endothelium by extracellularly generated oxgyen radicals. J. Biol. Chem. 267:597-601.

33. Pinsky, D.J., Y. Naka, H. Liao, M.C. Oz, D.D. Wagner, T.N. Mayadas, R.C. Johnson, R.O. Hynes, M. Heath, C.A. Lawson, et al. 1996. Hypoxia-induced exocytosis of endothelial cell Weibel-Palade bodies. A mechanism for rapid neutrophil recruitmant after cardiac preservation. J. Clin. Invest. 97:493-500.

34. Arnould, T., C. Michiels, and J. Remacle. 1993. Increased PMN adherence on endothelial cells after hypoxia: involvement of PAF, CD18/CD11b, and ICAM-1. Am. J. Physiol. 264:C1102-C1110.

35. Lawson, C.A., H. Liao, B. van Aken, D.J. Loskutoff, D.M. Stern, and D.J. Pinsky. 1995. Hypoxia-induced murine plasminogen activator inhibitor-1 expression: a potential mechanism for hypoxia-induced thrombosis. Anesth. Analg. 80:S269 (Abstr.)

36. Kuwabara, K., S. Ogawa, M. Matsumoto, S. Koga, M. Clauss, D.J. Pin sky, P. Lyn, J. Leavy, L. Witte, J. Joseph-Silverstein, et al. 1995. Hypoxia-mediated induction of acidic/basic fibroblast growth factor and platelet-derived growth factor in mononuclear phagocytes stimulates growth of hypoxic endothelial cells. Proc. Natl. Acad. Sci. USA. 92:4606-4610.

37. Knighton, D., T. Hunt, H. Scheuensthl, B. Halliday, Z. Werb, and M. Banda. 1983. Oxygen tension regulates the expression of angiogenesis factor by macrophages. Science (Wash. DC). 221:1283-1285.

38. Olman, M.A., N. Mackman, C.L. Gladson, K.M. Moser, and D.J. Loskutoff. 1995. Changes in procoagulant and fibrinolytic gene expression during bleomycin-induced lung injury in the mouse. J. Clin. Invest. 96:1621-1630.

39. Compeau, C.G., J. Ma, K.N. DeCampos, T.K. Waddell, G.F. Brisseau, A.S. Slutsky, and O.D. Rotstein. 1994. In situ ischemia and hypoxia enhance alveolar macrophage tissue factor expression. Am. J. Respir. Cell. Mol. Biol. 11: 446-455.

40. Maugeri, N., V. Evangelista, A. Celardo, G. Dell'Elba, N. Martelli, P. Piccardoni, G. de Gaetano, and C. Cerletti. 1994. Polymorphonuclear leukocyte-platelet interaction: role of P-selectin in thromboxane $\mathrm{B}_{2}$ and leukotriene $\mathrm{C}_{4}$ cooperative synthesis. Thromb. Haemost. 72:450-456.

41. Tomasulo, P.A., J. Levin, P.A. Murphy, and J.A. Winkelstein. 1977. Biological activities of tritiated endotoxins: Correlation of the Limulus lysate assay with rabbit pyrogen and complement-activation assays for endotoxin. $J$. Lab. Clin. Med. 89:308-315.

42. Carmeliet, P., J.M. Stassen, L. Schoonjans, B. Ream, J.J. van den Ooord, M. De Mol, R.C. Mulligan, and D. Collen. 1993. Plasminogen activator inhibitor-1 gene deficient mice: II. Effects on hemostasis, thrombosis, and fibrinolysis. J. Clin. Invest. 92:2756-2760.

43. Carmeliet, P., L. Schoonjans, L. Kieckens, B. Ream, J. Degen, R. Bronson, R. De Vos, J.J. van den Oord, D. Collen, and R.C. Mulligan. 1994. Physiological consequences of loss of plasminogen activator gene function in mice. Nature (Lond.). 368:419-424.

44. Weiler-Guettler, H., W.C. Aird, M. Husain, H. Rayburn, and R.D. Rosenberg. 1996. Targeting of transgene expression to the vascular endothelium of mice by homologous recombination at the thrombomodulin locus. Circ. Res. 78:180-187 